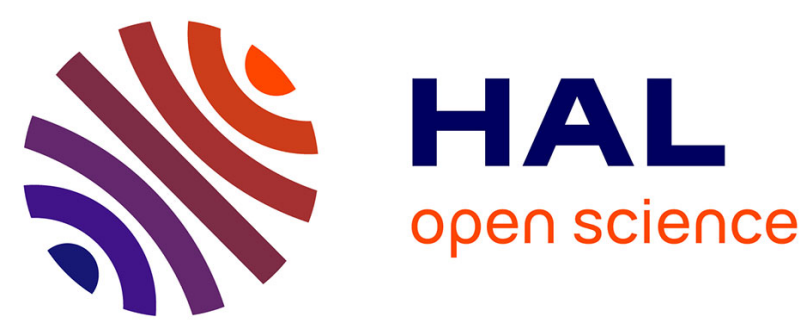

\title{
Direct-to-metal UV-cured hybrid coating for the corrosion protection of aircraft aluminium alloy
}

Lingli Ni, Abraham Chemtob, Céline Croutxé-Barghorn, Nadia Moreau, Thierry Bouder, Sébastien Chanfreau, Nadine Pébère

\section{To cite this version:}

Lingli Ni, Abraham Chemtob, Céline Croutxé-Barghorn, Nadia Moreau, Thierry Bouder, et al.. Direct-to-metal UV-cured hybrid coating for the corrosion protection of aircraft aluminium alloy. Corrosion Science, 2014, 89, pp.242-249. 10.1016/j.corsci.2014.09.006 . hal-02490561

\section{HAL Id: hal-02490561 https://hal.science/hal-02490561}

Submitted on 25 Feb 2020

HAL is a multi-disciplinary open access archive for the deposit and dissemination of scientific research documents, whether they are published or not. The documents may come from teaching and research institutions in France or abroad, or from public or private research centers.
L'archive ouverte pluridisciplinaire HAL, est destinée au dépôt et à la diffusion de documents scientifiques de niveau recherche, publiés ou non, émanant des établissements d'enseignement et de recherche français ou étrangers, des laboratoires publics ou privés. 


\section{OATAO \\ Open Archive Toulouse Archive Ouverte}

\section{Open Archive Toulouse Archive Ouverte (OATAO)}

OATAO is an open access repository that collects the work of Toulouse researchers and makes it freely available over the web where possible

This is an author's version published in: http://oatao.univ-toulouse.fr/25466

Official URL: https://doi.org/10.1016/j.corsci.2014.09.006

\section{To cite this version:}

Ni, Lingli and Chemtob, Abraham and Croutxé-Barghorn, Céline and Moreau, Nadia and Bouder, Thierry and Chanfreau, Sébastien $\rightleftharpoons$ and Pébère, Nadine metal $U V$-cured hybrid coating for the corrosion protection of aircraft aluminium alloy. (2014) Corrosion Science, 89. 242-249. ISSN 0010-938X

Any correspondence concerning this service should be sent to the repository administrator: tech-oatao@listes-diff.inp-toulouse.fr 


\title{
Direct-to-metal UV-cured hybrid coating for the corrosion protection of aircraft aluminium alloy
}

\author{
Lingli $\mathrm{Ni}^{\mathrm{a}}$, Abraham Chemtob ${ }^{\mathrm{a}, *}$, Céline Croutxé-Barghorn ${ }^{\mathrm{a}, *}$, Nadia Moreau $^{\mathrm{a}, \mathrm{b}}$, Thierry Bouder $^{\mathrm{b}}$, \\ Sébastien Chanfreau ${ }^{c}$, Nadine Pébère ${ }^{c}$ \\ ${ }^{2}$ Laboratory of Photochemisty and Macromolecular Engineering ENSCMu, University of Haute-Alsace, 3-bis rue Alfied Werner, 68093 Mulhouse Cedex, France \\ b SOCOMORE, ZI du Prat, CS 23707, 56037 Vannes Cedex, France \\ ' Université de Toulouse, CIRIMAT, UPS/INPT/CNRS, ENSIACET, 4 allée Emile Monso, CS 44362, 31030 Toulouse Cedex 4, France
}

\section{A R T I C L E I N F O}

Keywords:

A. Aluminium

A. Polymer

B. EIS

B. IR spectroscopy

C. Passive films

C. Polymer coatings

\begin{abstract}
A B S T R A C T
Finding eco efficient and environmentally viable alternatives to chromate coatings represents a funda mental milestone in the aerospace industry. Here, we show a chromate free approach to protective hybrid coatings on aluminium alloy (AA2024 T3) departing from photoinduced sol gel and cationic polymerizations. Beginning with a film of $n$ alkyltrimethoxysilane and diepoxy monomer, we rely on photogenerated superacids to induce the single step formation of two inorganic and organic barrier networks. Such system combines the unique aspects of photopolymerization including fast reactions, temporal control, solvent free composition and temperature independence. Used without chemical conversion coating or anodizing, some films have passed $2000 \mathrm{~h}$ of salt spray testing.
\end{abstract}

\section{Introduction}

2024 T3 aluminium alloy (AA2024 T3) is widely employed in the aeronautical industry because of its unique set of properties, such as a well balanced weight to strength ratio, high fracture toughness and low cost [1]. In this alloy, the presence of copper and magnesium intermetallic particles allows a mechanical rein forcement of the aluminium matrix, but at the expense of a higher sensitivity to localised corrosion [2,3]. To protect the alloy sub strate against corrosion, the usual strategy relies on a stack of three different layers. Except for the top organic layer (top coat), hexava lent chromate compounds are generally present as salts in the first surface treatment layer (anodizing or conversion film), and as pig ments in the second layer (primer) [4]. $\mathrm{Cr}(\mathrm{VI})$ is highly effective in promoting passive and active corrosion protection. However, it is now widely recognized as a toxic, carcinogenic, mutagenic and environmentally hazardous substance [5]. Due to health issues and stricter legislations, the replacement of chromates has become a critical issue for the aircraft industry.

\footnotetext{
* Corresponding authors. Tel.: +33 38933 5030; fax: +33 389335014 (A. Chemtob) Tel.: +33 38933 5017; fax: +33 389335014 (C. Croutxé Barghorn). E-mail addresses: abraham,chemtob@uha,fr (A. Chemtob), celine.croutxebarghorn@uha.fr (C. Croutxé-Barghom).
}

Several approaches have been developed over the last 20 years in attempts to replace chromate based surface treatments and primers, but very few offer equivalent technical performances in regard to corrosion protection, adhesion and solvent resistance [6 9]. Among them, sol gel inorganic coatings have attracted con siderable interest mainly as pre treatment [ 10 12]. The pioneering studies of Sugama $[13,14]$ and Blohowiak $[15,16]$ in the mid 90s have revealed the numerous advantages pertaining to alkoxysi lane based sol gel chemistry: a low temperature process prevent ing the thermal modification of metal [17], a dense silica network acting as a physical passive barrier [18] and a strong interfacial adhesion to the substrate [19]. Subsequently, the addition of organic moieties has enabled to increase film thickness, hydropho bicity and resistance to cracking [ $\left.\begin{array}{ll}20 & 22\end{array}\right]$. The building block for the formation of these hybrid organic inorganic structures are organ oalkoxysilane precursors of the form $\mathrm{R}\left[\mathrm{SiX}_{3}\right]_{n}$, wherein $\mathrm{R}$ is a cova lently bound organic fragment and $n$ is the number of $\mathrm{SiX}_{3}$ hydrolysable group $\left(X=\mathrm{OCH}_{3}, \mathrm{OCH}_{2} \mathrm{CH}_{3}\right)$. Their sol gel polymeri zation proceeds by hydrolysis and sequential $\mathrm{Si} O \mathrm{Si}$ condensation reactions to afford a $\mathrm{R}\left[\mathrm{SiO}_{1.5}\right]_{n}$ polysilsesquioxane structure con taining a polysiloxane network covalently connected to the organic units. In the field of corrosion protection, the most common organosilanes used are mono silylated precursors $(n=1)$ bearing alkyl [23,24], epoxy [25 27] or vinyl [28 30] groups, and to a minor extent bis silylated $(n=2)$ precursors [31 34]. More 
recently, corrosion inhibitors were added to hybrid sol gel films either directly [35] or as micro or nano capsules [36,37], these lat ter serving as host reservoirs in order to provide additional active corrosion protection when the coating is locally damaged.

Despite the abundance of literature in the subject, very few hybrid sol gel coatings have successfully met the stringent aircraft specifications. For instance, organosilicate films such as Socogel ${ }^{\circledR}$ or Boegel ${ }^{\circledR}$ are exploited industrially as adhesion promoters to enhance the protection performance of chromated primers [38]. At the lab scale, the salt spray resistance provided by sol gel films alone vary generally from 100 to $500 \mathrm{~h}$ on AA2024 T3 depending on the thickness ( $110 \mu \mathrm{m})$ and film structure [8,39]. With regard to processing, sol gel chemistry raises problems of low reactivity and high volatile organic compounds concentrations since the sol is prepared in diluted alcoholic solutions [40]. Other challenges are related to the mixing of several components (catalyst, solvent, and precursors), the sensitivity to temperature or humidity, and the short pot life of the resultant preparation. In order to be more efficient and environmentally compliant, we have turned our attention to a solvent free UV driven technology yielding hybrid barrier films in a fast single step, and without the requirement of surface treatment. As depicted in Scheme 1, our approach for the synthesis of this "superprimer" is based on a twin sol gel and organic photopolymerization catalyzed by highly efficient photo generated superacids. To be as close as possible to industrial requirements, irradiation is performed under a UV conveyor used conventionally for the series production of UV curable industrial coatings on metal (can, coil and automotive coatings) but also wood and plastic [41]. Applied directly on metal (without surface treatment layer), the liquid film is initially comprised of diepoxy monomer, $n$ alkyltrimethoxysilane precursor $\left(\mathrm{C}_{n} \mathrm{H}_{2 n+1} \mathrm{Si}\left(\mathrm{OCH}_{3}\right)_{3}\right.$, $n=4$ 16) and diaryl iodonium hexafluorophosphate salt acting as a photoacid generator (PAG), which are all stable, easy to use and commercially available products [42]. Upon UV exposure, in situ photogenerated $\mathrm{H}^{+} \mathrm{PF}_{6}^{-}$catalyst triggers both sol gel process of trimethoxysilyl functions and cationic ring opening polymeriza tion (ROP) of epoxy functions [43,44]. This results in the one step formation of a $13 \mu \mathrm{m}$ thick $\operatorname{poly}(n$ alkysilsesquioxane)/polyether nanocomposite film providing, under certain conditions, promising barrier protection even in the absence of corrosion inhibitors $[45,46]$. Using a range of spectroscopic and microscopic tech niques, we show that corrosion resistance is determined by the structural characteristics of the two non covalently bound poly mers. Clearly, hydrophobicity of the alkyl chains (i) and cross link ing of the two organic inorganic networks (ii) are essential features to prevent ingress and diffusion of aggressive species (water, ions, and oxygen). In addition, thermodynamic and kinetic considerations on network compatibility (iii) and formation rate (iv) respectively have been addressed to give a comprehensive pic ture of the protection mechanism. Understanding the effect of these four key features has paved the way to a novel hybrid photopolymer coating delivering corrosion resistance and adhe sion for aluminium substrate.

\section{Experimental section}

\subsection{Chemicals}

All $n$ alkyltrimethoxysilane precursors were purchased from ABCR: $n$ butyltrimethoxysilane (C ${ }_{4}$ TMS, $\left.97 \mathrm{wt} . \%\right), n$ octyltrimeth oxysilane ( $\left.\mathrm{C}_{8} \mathrm{TMS}, 97 \mathrm{wt} . \%\right), n$ dodecyltrimethoxysilane $\left(\mathrm{C}_{12} \mathrm{TMS}\right.$, $95 \mathrm{wt} . \%), n$ hexadecyltrimethoxysilane ( $\left.C_{16} \mathrm{TMS}, 90 \mathrm{wt} . \%\right)$. Their chemical structures are shown in Table 1 . The epoxy resin based on hydrogenated diglycidyl ether of bisphenol A (Epalloy 5000) was provided by CVC Chemicals. The photoacid generator 4 methylphenyl[4 (2 methylpropyl) phenyl] iodonium hexafluoro phosphate was supplied by BASF. Byk 333 (BYK Chemie) is a surface wetting agent based on a polyether modified polydimethylsiloxane. All chemicals were used as received, without any further purification.

\subsection{T3. aluminium alloy panel preparation}

The $2024 \mathrm{~T} 3$ aluminium panels (AA2024 T3, $125 \times 80 \times 1.6 \mathrm{~mm}$ ) were provided by Airbus Group Innovations and prepared with adapted home made and confidential Airbus Group Innovations surface preparation. Although the surface prep aration is critical for anticorrosive properties, the procedure used herein is general and has not been modified specifically for the present hybrid sol gel coating.

\subsection{Preparation of poly(n alkylsilsesquioxane)/polyether hybrid films}

The hybrid precursor was mixed with Epalloy 5000 organic resin at a concentration between 0 and $60 \mathrm{wt} . \%$. Subsequently, 0.5 wt.\% of Byk 333 and 2 wt.\% of PAG were added to this homoge neous solution labelled $\mathrm{E}_{100-x} \mathrm{C}_{n} \mathrm{TMS}_{x}$ with $x$ the weight fraction in organosilane. Despite the use of hydrophobic $n$ alkylsilane and epoxy resins, there is no insolubility issues to worry about because solvent and hydrolysed products are absent from the initial formu lation. The resultant photolatent formulation was applied onto prepared AA2024 T3 aluminium alloy substrates using an Elcome ter 4340 automatic film applicator equipped with a wire wound bar. A reproducible liquid film thickness of ca. $13 \pm 3 \mu \mathrm{m}$ was obtained whatever the formulation composition. The films were irradiated at room temperature through 5 successive passes under a UV conveyor (Fusion UV) including a microwave H lamp (Fusion) to yield cross linked hybrid films. A belt speed of $10 \mathrm{~m} \mathrm{~min}^{-1}$ was selected to ensure an overall light intensity of $1.46 \mathrm{~J} \mathrm{~cm}^{-2}$ per pass $\left[\mathrm{UV}_{\mathrm{C}}(250260 \mathrm{~nm})=0.09 \mathrm{~J} \mathrm{~cm}^{-2}, \mathrm{UV}_{\mathrm{B}}(280320 \mathrm{~nm})=0.42 \mathrm{~J} \mathrm{~cm}^{-2}\right.$, $\left.\mathrm{UV}_{\mathrm{A}}(320390 \mathrm{~nm})=0.45 \mathrm{~J} \mathrm{~cm}^{-2}, \mathrm{UV}_{\mathrm{V}}(395445)=0.50 \mathrm{~J} \mathrm{~cm}^{-2}\right]$.
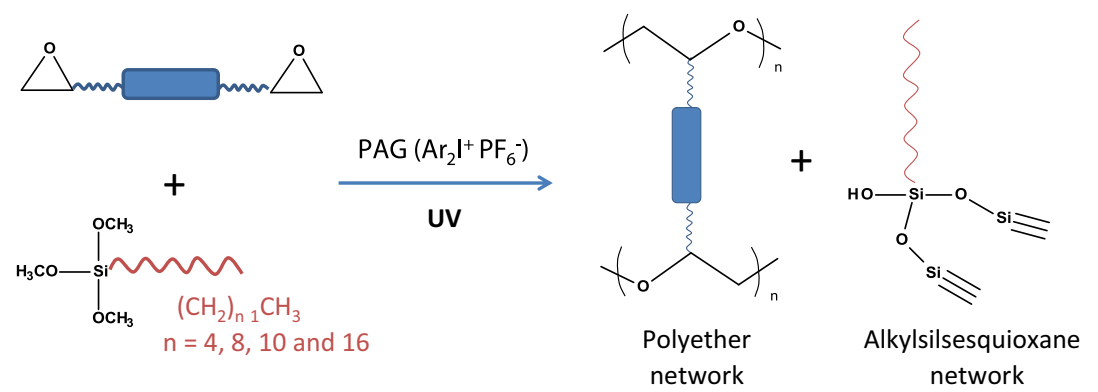

Scheme 1. Photoinduced formation of two non-covalently bound networks via photoacid-catalyzed sol-gel and epoxy ROP. 
Table 1

Chemical structures of the $n$-alkyltrimethoxysilane precursors, diepoxy monomer and photoacid generator used for the direct-to-metal hybrid coating.

\begin{tabular}{|c|c|c|}
\hline Compound & Chemical structure & Weight ratio (wt.\%) \\
\hline n-Butyl trimethoxysilane & $\begin{array}{c}\mathrm{OCH}_{3} \\
1 \\
\mathrm{O}-\mathrm{Si}- \\
1 \\
\mathrm{O} \\
\mathrm{OCH}_{3}\end{array}$ & $0-60$ \\
\hline n-Octyl trimethoxysilane & & $0-60$ \\
\hline n-Dodecyl trimethoxysilane & $\mathrm{OCH}_{3}$ & $0-60$ \\
\hline$n$-Hexadecyl trimethoxysilane & $\begin{aligned} \mathrm{H}_{3} \mathrm{CO}-\mathrm{Si}- \\
1 \\
\mathrm{OCH}_{3}\end{aligned}$ & $0-60$ \\
\hline Epalloy 5000 & & $0-40$ \\
\hline PAG & & $\begin{array}{l}2 \\
\text { (with respect to the sum of monomer and precursor) }\end{array}$ \\
\hline
\end{tabular}

During the irradiation process, the relative humidity, checked with a hygrometer, was found to be between $30 \%$ and $35 \%$.

\subsection{Characterization techniques}

\subsubsection{Salt spray test (SST)}

Corrosion protection performance of the different coatings was evaluated by neutral SST according to ASTM B117 Salt Spray Test standard (and ISO 9227) in the same fog chamber. For each film composition, three specimens were exposed under similar condi tions to a salty fog atmosphere generated by a $5 \mathrm{wt} . \%$ aqueous $\mathrm{NaCl}$ solution ( $\mathrm{pH}$ range from 6.5 to 7.2 and temperature: $35^{\circ} \mathrm{C} \pm 2{ }^{\circ} \mathrm{C}$ ). ASTM B117 specifies the apparatus, the reagents and the procedure to be used in conducting the neutral salt spray. In our case, the per iod of exposure was varied (400 $2800 \mathrm{~h}$ ) without interruption and the test specimens had typically a size of $120 \times 80 \times 1.2 \mathrm{~cm}$. Prior to exposure, the coated substrate was scratched (cross scratch). Whilst the use of scratched specimens in SST is not common for the characterization of anodizing or conversion film alone, it is widespread for primers. Since the objective of this study is the syn thesis of a "superprimer" that can substitute both for the first sur face treatment layer surface and the second layer of primer, a scratch was systematically carried out for all samples. After a given exposure time, the three samples were washed in clean running water to remove salt, and then a picture was taken immediately without drying. The reproducibility was first checked, and a detailed examination of the corrosion points (number, size and position), blisters as well as change of colour was made. The partic ular requirements are the absence of blistering, and extended corrosion on either side of the scratch (no more than $1.25 \mathrm{~cm}$ ).

\subsubsection{Electrochemical impedance spectroscopy (EIS)}

A three electrode electrochemical cell was used in EIS measure ments. A coated specimen was used as working electrode. A cylin drical plexiglas tube was assembled on top of the coated sample (exposed surface area: $24 \mathrm{~cm}^{2}$ ) and filled with the aggressive solu tion prepared from distilled water by adding $0.5 \mathrm{M} \mathrm{NaCl}$ (reagent grade). A large platinum sheet and a saturated calomel electrode were used as counter and reference electrodes, respectively. The electrochemical cell was kept at room temperature and open to air. Electrochemical impedance measurements were carried out using a Biologic VSP apparatus. The impedance diagrams were obtained under potentiostatic conditions at the corrosion potential over a frequency range of $200 \mathrm{KHz}$ to $3 \mathrm{MHz}$ with 10 points per decade using a $20 \mathrm{mV}$ peak to peak sinusoidal voltage. The elec trochemical behaviour of the coatings was characterized for differ ent exposure times to the aggressive solution ranging from $2 \mathrm{~h}$ to $336 \mathrm{~h}$ (14 days).

\subsubsection{Real time Fourier transform infrared spectroscopy (RT FTIR)}

Epoxy photopolymerization and methoxy hydrolysis conver sion time curves were obtained by RT FTIR performed in transmis sion. In a typical experiment, the liquid $\mathrm{C}_{n} \mathrm{H}_{2 n+1} \mathrm{Si}\left(\mathrm{OCH}_{3}\right)_{3} /$ monomer/PAG film was exposed at room temperature to UV light and also to an IR analytical beam. A particular UV irradiation source was implemented to allow the acquisition of infrared spec tra throughout the irradiation process. The $\mathrm{C}_{n} \mathrm{TMS}_{x} \mathrm{E}_{100-x}$ film was deposited on $\mathrm{BaF}_{2}$ pellets and irradiated by the polychromatic light of a mercury xenon lamp (Hamamatsu, L8252, $200 \mathrm{~W}$ ) coupled with a flexible light guide at an incident light intensity of $200 \mathrm{~mW} \mathrm{~cm}^{-2}$. The end of the optical guide was placed at a dis tance of $3 \mathrm{~cm}$ from the film and directed at an incident angle of $90^{\circ}$ onto the sample. The IR spectra were recorded with a Bruker Vertex 70 equipped with a liquid nitrogen cooled mercury cad mium telluride detector. The resolution of the infrared spectra was $4 \mathrm{~cm}^{-1}$. During UV irradiation, the decreased absorbance of the $\mathrm{C} \mathrm{H}$ epoxy stretching vibration band at $3050 \mathrm{~cm}^{-1}$ was assessed to monitor epoxy conversion of the Epalloy 5000 monomer. The decay of the symmetrical $\mathrm{C} \mathrm{H}$ vibration $\left(v_{\text {sym }}\left(\mathrm{Si} O \mathrm{CH}_{3}\right)\right)$ IR absorption at $2840 \mathrm{~cm}^{-1}$ was used to determine the hydrolysis degree throughout the irradiation time. The relative rate of methoxysilyl hydrolysis and epoxy conversion furnished by RT FTIR was taken as an indicator of the concomi tancy of both polymerizations.

\subsubsection{Solid state nuclear magnetic resonance (NMR)}

The ${ }^{29} \mathrm{Si}\left({ }^{13} \mathrm{C}\right)$ cross polarization magic angle spinning (CP MAS) solid state NMR spectra was performed on a Bruker Avance II 400 spectrometer with a Bruker double channel 7 (4) mm probe. Zirco nium rotors were employed at 79.48 (100.6) $\mathrm{MHz}$ using a recycling delay of $5(5) \mathrm{s}$, a spinning frequency of $4(12) \mathrm{KHz}$ and a contact time of $4(1) \mathrm{ms} .{ }^{29} \mathrm{Si}$ chemical shift is relative to tetramethylsilane.

\subsubsection{Water contact angle}

The contact angle measurements were performed with a KRUSS DSA 100 equipped with a video camera. Each analysis was made at room temperature by means of the sessile drop technique. Ten 
measurements were performed on the same sample to obtain an averaged value.

2.4.6. Scanning electron microscopy energy dispersive $X$ ray analysis (SEM EDX)

Morphology of the samples was characterized by SEM (FEI Quanta 400 microscope working at $30 \mathrm{kV}$ ). Before the analysis, the samples were coated with a $15 \mathrm{~nm}$ thick layer of gold to reduce the charging effect on the surface. Chemical composition of film interfaces was determined by EDX acquired as point and/or line scans. All analyses were repeated four times and the results were averaged out.

\subsubsection{UV Visible spectrophotometry}

UV Visible spectra were recorded from $300 \mathrm{~nm}$ to $800 \mathrm{~nm}$ on a Shimadzu UV 1601 spectrometer with UV cured films prepared on borosilicate glass substrate.

\section{Results and discussion}

\subsection{Hybrid film characterization}

Nanometre scale structure is primarily responsible for the cor rosion performance of hybrid sol gel films. In our case, the relative simplicity of the three component system (hybrid precursor/ organic monomer/PAG) is conducive to an in depth study of the structure properties relationship. Four structural data having a presumed protective effect are successively investigated including network cross linking, silsesquioxane hydrophobicity, photopoly merization kinetics and the thermody namiccompatibility between the two organic and inorganic networks.

\subsubsection{Double cross linked networks}

After UV exposure of a $\mathrm{C}_{n} \mathrm{H}_{2 n+1} \mathrm{Si}\left(\mathrm{OCH}_{3}\right)_{3} /$ monomer/PAG film, the extent of cross linking of the polysilsesquioxane and polyether networks was examined using ${ }^{29} \mathrm{Si}$ and ${ }^{13} \mathrm{C}$ CP MAS NMR respectively. The ${ }^{29} \mathrm{Si}$ NMR spectra in Fig. $1 \mathrm{~A}$ were obtained with four different alkyl chain lengths ( $n=4,8,12$ and 16) at a constant weight concentration in alkyltrimethoxysilane (50 wt.\%). In most cases, the spectra are dominated by $\mathrm{T}^{3}\left(-\mathrm{Si}(\mathrm{OSi})_{3}\right)$ and $\mathrm{T}^{2}$ $\left(-\mathrm{Si}(\mathrm{OH})(\mathrm{OSi})_{2}\right)$ species, which are the most condensed siloxane structures. Clearly, these results demonstrate the use of diaryl iodonium hexafluorophosphate as an efficient in situ generated cat alyst for the hydrolysis and condensation of these organosilanes. Furthermore, a strong dependence of the substituent hindrance on the degree of condensation is observed. Thus, the ratio of the less substituted $\mathrm{T}^{1}$ siloxane species $\left(-\mathrm{Si}(\mathrm{OH})_{2}(\mathrm{OSi})\right)$ is significantly stronger upon increasing the chain length. In Fig. $1 \mathrm{~B}$, the ${ }^{13} \mathrm{C}$ spec trum of the $n \mathrm{C}_{8} \mathrm{TMS}_{50} \mathrm{E}_{50}$ film shows a complete epoxy ring open ing, reflected by the absence of epoxy carbons arising only in the monomer at $\delta \approx 49 \mathrm{ppm}$. In contrast with the siloxane network, only qualitative evidence of epoxy cross linking is provided by two broad peaks at $71.0 \mathrm{ppm}$ and $79.6 \mathrm{ppm}$ assigned to the two polyether carbons ( $\mathrm{CH}_{2} \mathrm{CHR} O$ ). In addition, the breadth of this latter signals and the emergence of an additional peak at ca. $58 \mathrm{ppm}$ ascribed to methoxy carbons are indicative of competitive transfer reactions with methanol molecules released by hydrolysis reac tions (sol gel process). Propagation reactions leading to chain growth, and transfer reactions interrupting this growth are described in the inset of Fig. 1B. The presence of deleterious transfer reactions involving hydroxyl containing compounds is well described in cationic polymerization $[47,48]$. However, it is difficult to quantify precisely their impact on the cross linking of the polyether network. In addition, reducing their level remains tricky in our tandem photopolymerization process because they are
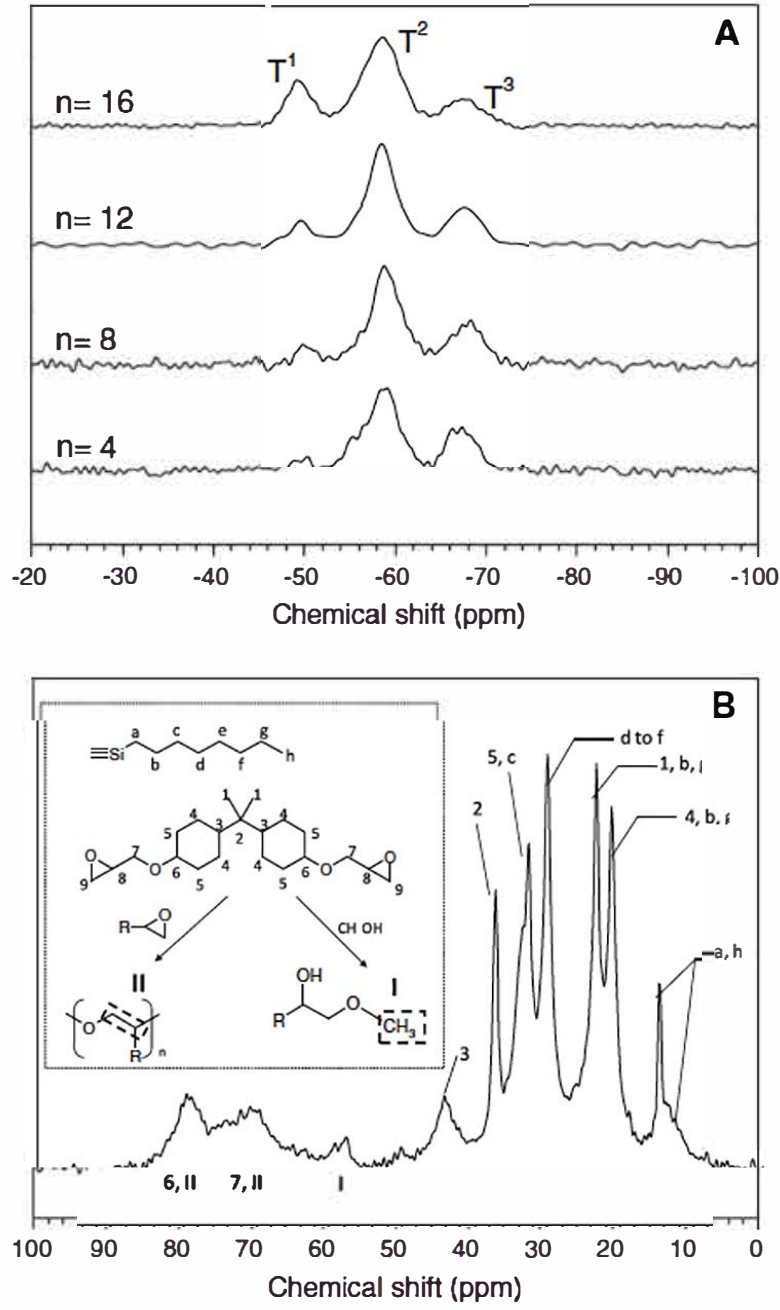

Fig. 1. (A) ${ }^{29} \mathrm{Si}$ CP-MAS NMR spectra of UV cured $C_{n} \mathrm{TMS}_{50} \mathrm{E}_{50}$ films $(n=4,8,12$ and 16); (B) ${ }^{13} \mathrm{C}$ CP-MAS NMR spectrum of the $U V$-cured $C_{8} T_{M S} S_{50} E_{50}$ film (inset: propagation and transfer reactions to methanol in a cationic polymerization process, $R=q_{0} \mathrm{O}_{0}$ )

initiated by adventitious alcohol species continuously released by the sol gel process.

\subsection{Film hydrophobicity}

Contact angle measurements were performed to assess the change of hydrophobicity resulting from the addition of $n$ alkyltri methoxysilane. As shown in Table 2, the incorporation of only 5 wt.\% $n \mathrm{C}_{8}$ TMS is sufficient to increase the water contact angle from $76^{\circ}$ to $101^{\circ}$. To enhance the concentration even further hardly change the wetting properties $\left(\approx 100^{\circ}\right)$, showing that a surface saturation is achieved at rather low organosilane content. In

Table 2

Effect of the concentration of $\mathrm{C}_{8}$ TMS on the surface properties of $C_{n} T M S_{x} E_{100_{-x}}$ films.

\begin{tabular}{cc}
\hline $\begin{array}{l}C_{8} \text { TMS concentration } \\
(\text { wt } \%)\end{array}$ & $\begin{array}{l}\text { Contact } \\
\text { angles }\left({ }^{\circ}\right)\end{array}$ \\
\hline 0 & $76 \pm 2$ \\
5 & $100 \pm 2$ \\
10 & $102 \pm 2$ \\
20 & $99 \pm 2$ \\
40 & $101 \pm 2$ \\
50 & $101 \pm 2$ \\
60 & $102 \pm 2$ \\
\hline
\end{tabular}


several studies, minimization of interfacial energy by migration of low energy chemical groups to the air/film interface has proven to be an efficient method to limit water condensation, which is the first step before its ingress through the film [49]. Another way to evidence the preferential location of organosilane molecules at
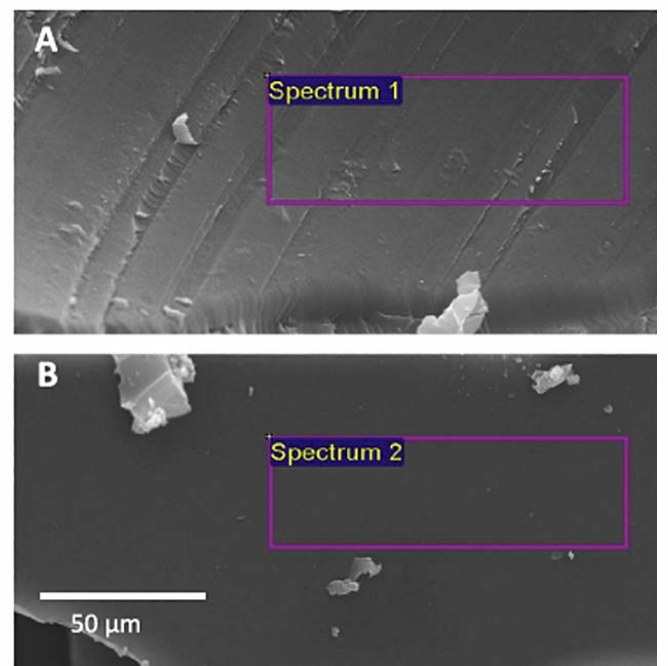

Fig. 2. SEM images showing the two sides of a $U V$-cured $C_{B} I M S_{50} E_{50}$ film after delamination on an aluminium alloy substrate: metal/film (A) and air/film (B) interfaces.
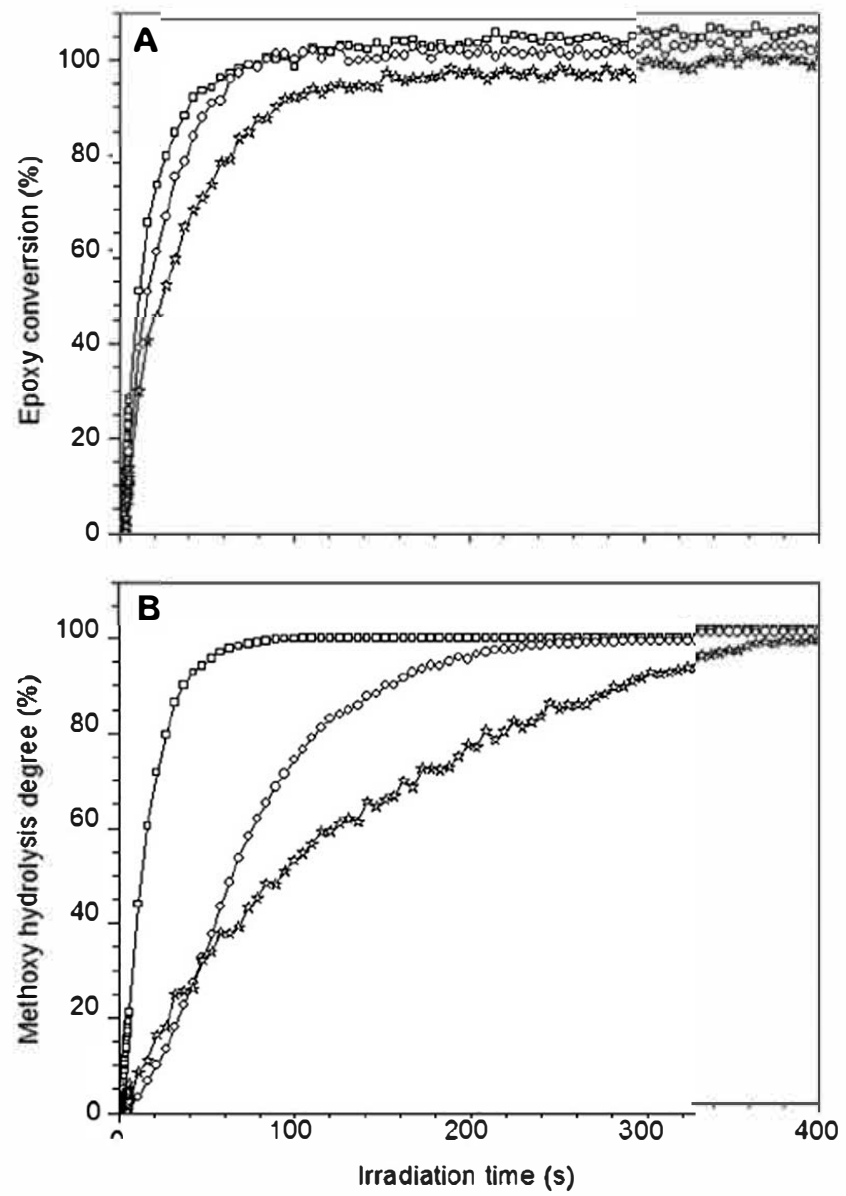

Fig. 3. Influence of alkyl chain length on kinetics of epoxy conversion $(A)$ and methoxysilyl hydrolysis (B) in the $\mathrm{C}_{n} \mathrm{TMS}_{50} \mathrm{E}_{50}$ films: $\mathrm{C}_{4} \mathrm{TMS}$ (square), $\mathrm{C}_{8} \mathrm{TMS}$ (circle) C 16 IMS (star) the air/film interface is to examine the difference of chemical com position between the two sides of the film after delamination on the aluminium substrate. As shown in Fig. 2, the smooth upperside and the rough underside of the $n \mathrm{C}_{8} \mathrm{TMS}_{50} \mathrm{E}_{50}$ film have been exam ined by SEM and compositionally probed by EDX. A higher $\mathrm{Si} / \mathrm{C}$ weight ratio $(0.3)$ is found at the air/film interface compared with the substrate/film interface ( 0.1 ), supporting a preferential concen tration of hybrid precursor at the external surface. Mechanistically, this result is consistent with the formation of transient mobile amphiphilic species $\left(\mathrm{C}_{n} \mathrm{H}_{2 n+1} \mathrm{Si}(\mathrm{OH})_{x}(\mathrm{OSi})_{3-x}\right)$ arising from hydroly sis and moving to the surface like surfactant before they are fixed by siloxane cross linking [50]. Additionally, the weight concentra tion in iodine at the metal/film interface ( $0.6 \mathrm{wt} . \%)$ is double than that detected at the air/film interface ( $0.3 \mathrm{wt} . \%)$, showing a higher local concentration in PAG $\left(\mathrm{Ar}_{2} \mathrm{I}^{+} \mathrm{PF}_{6}^{-}\right)$at the metal/film interface (vide infra, part 3.2).

\subsubsection{Organic inorganic polymerization kinetics}

In situ RT FTIR spectroscopy was used to monitor the kinetics of hydrolysis and ROP for three distinct $\mathrm{C}_{n} \mathrm{TMS}_{50} \mathrm{E}_{50}$ films ( $n=4,8$ and 16). In all instances, the conversion time curves in Fig. 3 show a fast and complete consumption of the epoxy and trimethoxysilyl functions. Whilst the ring opening is relatively insensitive to alkyl substituent hindrance, hydrolysis becomes slower with longer car bon chain lengths. But the most salient feature is that these two photoinduced processes take place on a similar time scale. Whilst the concomitancy between both reactions is particularly marked
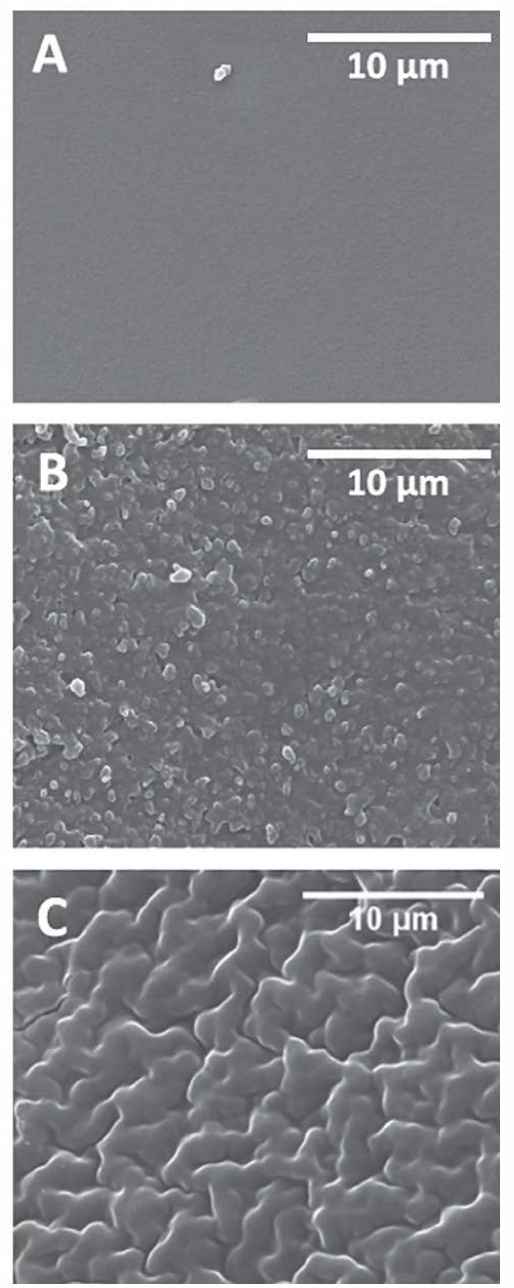

Fig. 4. SEM images of the hybrid films containing three different $n$-alkylsilane ( 50 wt.\%): (A) $\mathrm{C}_{8} \mathrm{TMS}_{50} \mathrm{E}_{50}$. (B) $\mathrm{C}_{12} \mathrm{TMS}_{50} \mathrm{E}_{50}$ and (C) $\mathrm{C}_{16} \mathrm{TMS}_{50} \mathrm{E}_{50}$ 
with the $n$ butyl precursor, difference in conversion rates tends to widen with longer alkyl chains. In a dual process involving two (a priori) incompatible organic and inorganic networks, reaction kinetics are assumed to have strong impact on the final structure. In particular, the minimization or elimination of macrophase sep aration can be favoured kinetically through two cross linking reac tions occurring at similar time scales and rapidly enough. In the present case, concomitant and fast organic inorganic polymeriza tions can drive the formation of kinetically trapped nanocompos ites, Whilst thermodynamically driven process would have promoted more composite like or segregated mixtures.

\subsubsection{Network compatibility}

Although all $n$ alkylsilane precursors are fully miscible with the diepoxy resin before reaction, the subsequent cross linking reac tions and the absence of covalent bonds between the two polymer

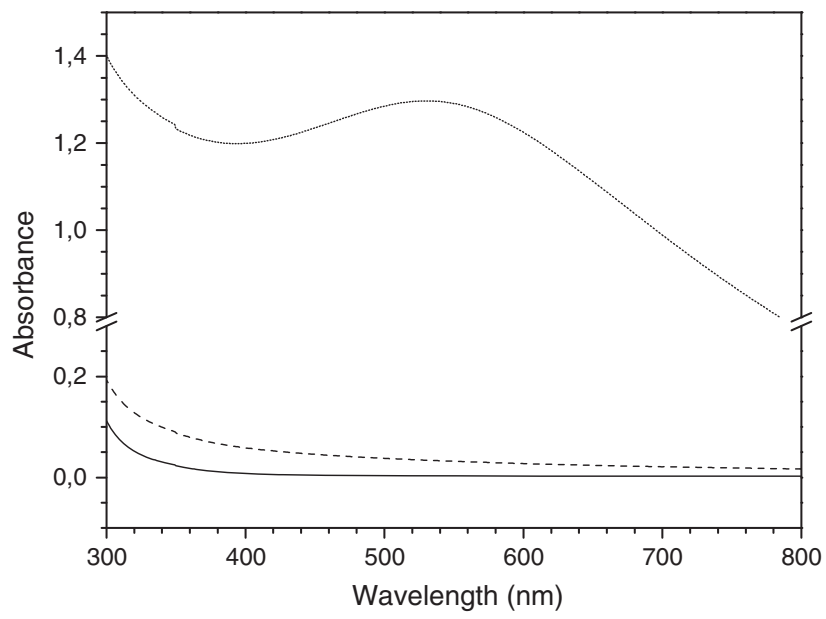

Fig. 5. UV-Visible spectra of the hybrid coatings: (-) $\mathrm{C}_{8} \mathrm{TMS}_{50} \mathrm{E}_{50},(--) \mathrm{C}_{12} \mathrm{TMS}_{50}$ $\mathrm{E}_{50}$, and $(\cdots) \mathrm{C}_{16} \mathrm{TMS}_{50} \mathrm{E}_{50}$. networks are clear challenges for the preservation of film homoge neity. SEM examination of the $\mathrm{C}_{8} \mathrm{TMS}$ based film $\left(\mathrm{C}_{8} \mathrm{TMS}_{50} \mathrm{E}_{50}\right)$ reveals a uniform and homogeneous surface morphology (Fig. 4A). By contrast, its replacement by $\mathrm{C}_{12} \mathrm{TMS}$ and $\mathrm{C}_{16} \mathrm{TMS}$ at similar con centration results in significant signs of phase separation increasing with the length of the alkyl chain (Fig. 4B and C). Accordingly, the optical properties of the film change from high transparency in the UV Vis range to much higher absorbance values when increas ing the alkyl chain length (Fig. 5). The formation of a phase segre gated structure in the presence of the longest alkyl chains $\left(\mathrm{C}_{12} \mathrm{TMS}\right.$ and $\left.\mathrm{C}_{16} \mathrm{TMS}\right)$ results in light scattering and significant light attenuation. Despite the relative simultaneity of both reactions for these three precursors, the incorporation of long alkyl chain $(n \geqslant 12)$ drives a phase separation consistent with a decreased affinity between the two networks. This suggests that not only kinetics but also thermodynamics determine the final structure.

\subsection{Corrosion protection properties}

A first diagnostic of the protecting ability of the films is given by the number and size of defects (etch pits) appearing on the coated surface after $400 \mathrm{~h}$ of exposure in the salt spray chamber (Fig. 6). For organic polyether films (sample A), more than 150 corrosion points are observed on coated AA2024 T3 substrate and the corro sion protection is considered ineffective. These features are circular with diameters between 1 and $3 \mathrm{~mm}$. Their density is drastically reduced by the addition of $n$ alkylsilane (samples B E). Examina tion of the effect of the alkyl chain length $\left(C_{n}\right.$ TMS, $n=4,8,10$ and 16) reveals that the alkyl chain length of $n=8$ (sample $\mathbf{C}$ ) yields the best protection, with no corrosion on the surface. In addition, the corrosion protection is strongly dependent on organosilane concentration and an optimal content in $\mathrm{C}_{8} \mathrm{TMS}$ is found at ca. 50 wt.\% (see Fig. S1 of electronic supporting information).

Fig. 7 shows a set of pictures of the $\mathrm{C}_{8} \mathrm{TMS}_{50} \mathrm{E}_{50}$ sample after dif ferent exposure times in the neutral salt spray chamber, up to $2800 \mathrm{~h}$. Aeronautical specifications require a resistance to salt

\begin{tabular}{c|c}
\hline Precursor & $\begin{array}{c}\text { Number of } \\
\text { corrosion } \\
\text { points: film } \\
\text { surface (and } \\
\text { cross cut) }\end{array}$ \\
\hline No & $>50(>100)$ \\
\hline $\mathrm{C}_{4}$ TMS & $20(10)$ \\
\hline $\mathrm{C}_{8}$ TMS & - \\
\hline $\mathrm{C}_{12}$ TMS & $>10(2)$ \\
\hline $\mathrm{C}_{16}$ TMS & $>100(3)$ \\
\hline
\end{tabular}
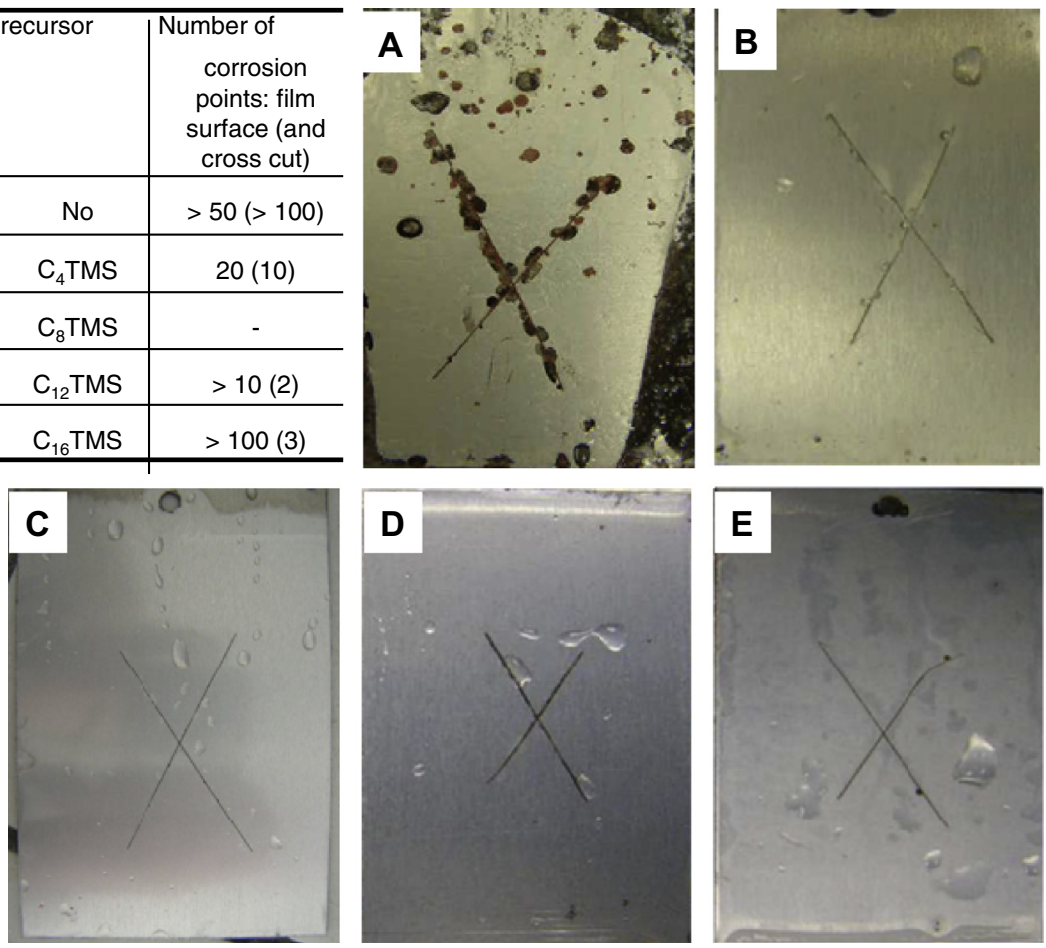

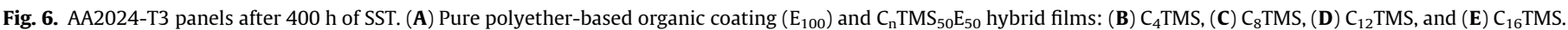




\begin{tabular}{c|c}
\hline $\begin{array}{c}\text { NSS } \\
\text { exposure } \\
\text { time }(\mathrm{h})\end{array}$ & $\begin{array}{c}\text { Number of } \\
\text { corrosion } \\
\text { points: film } \\
\text { surface (and } \\
\text { cross cut) }\end{array}$ \\
\hline 400 & - \\
\hline 670 & $3(5)$ \\
\hline 1300 & $10(10)$ \\
\hline 1800 & $10(10)$ \\
\hline 2800 & $10(10)$ \\
\hline
\end{tabular}
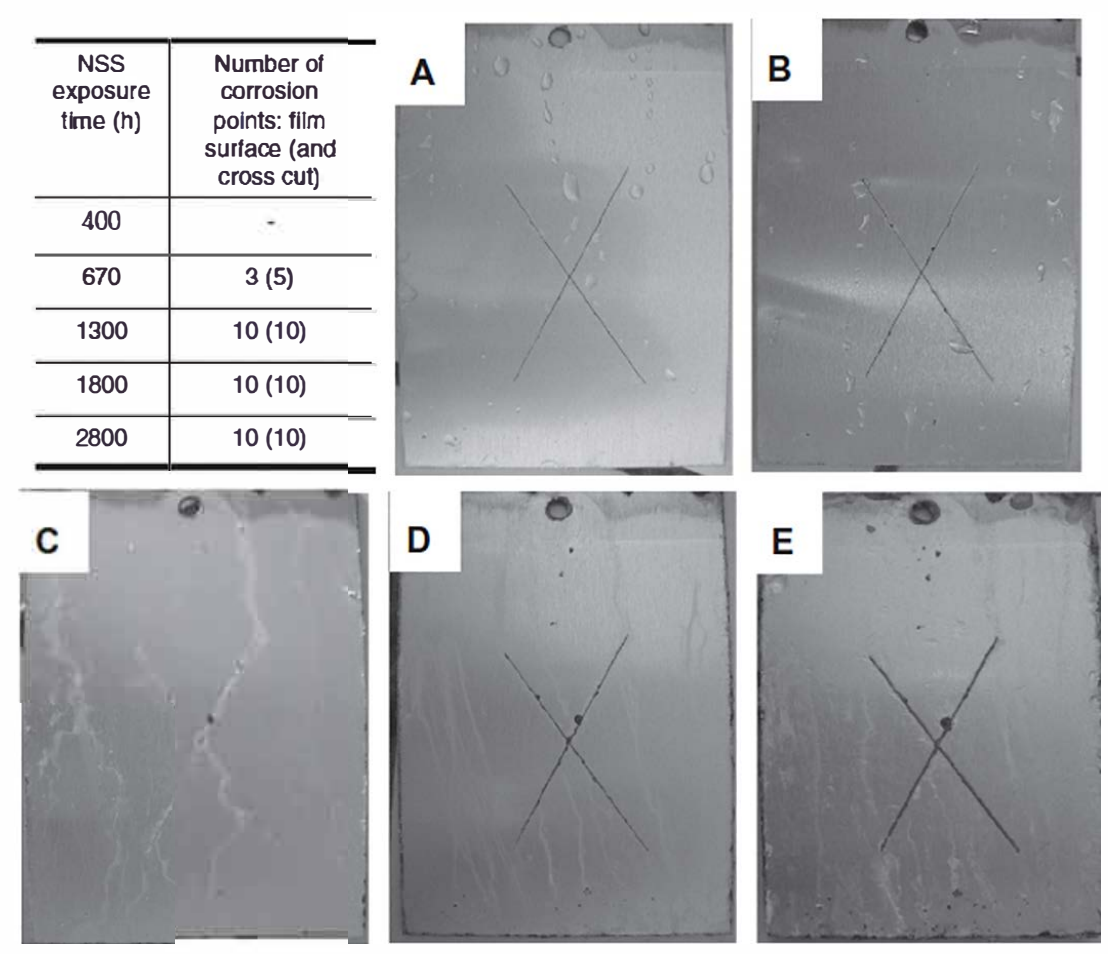

Fig. 7. Photographs of the $C_{8} T_{M S} E_{50}$ specimen after different exposure times in the SST: (A) $400 \mathrm{~h},(B) 670 \mathrm{~h},(\mathrm{C}) 1300 \mathrm{~h},(\mathrm{D}) 1800 \mathrm{~h}$, and (E) $2800 \mathrm{~h}$.

spray of at least $3000 \mathrm{~h}$ for the full 3 layer protective system (surface treatment layer + primer + top coat). Note that such per formance can be achieved without topcoat by a protective chromated primer applied on a conventional surface pretreatment like Alodine (chromated) or tartaric acid anodisation layer (non chromated). In our case, the protective performance of the "super primer" alone was assessed. The first corrosion points appear after

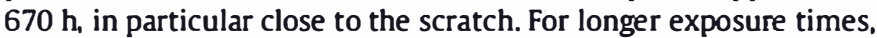
the defects increase only slightly in number and in size. However, there is no sign of blistering, loss of adhesion, change of colour, and no corrosion extending further than $2 \mathrm{~mm}$ on either side of the scratch. We think that $2800 \mathrm{~h}$ of SSI gives already a good insight into the potential of this novel photopolymer hybrid coating. Given the simplicity of our system, these results are promising, whilst offering a great scope for improvement with a more complex mul ticomponent formulation. Furthermore, the corrosion resistance of a complete system including both a "superprimer" and a topcoat will need to be tested, particularly because the hydrophobicity of the hybrid coating may raise some issues about top coat adhesion.

The behaviour of the $\mathrm{C}_{8} \mathrm{TMS}_{50} \mathrm{E}_{50}$ hybrid film has been also characterized by electrochemical impedance spectroscopy (EIS).
Fig. 8 reports impedance diagrams obtained after different immer sion times in a $0.5 \mathrm{M} \mathrm{NaCl}$ solution. The results, presented in Bode coordinates, show three time constants in the high (HF), medium (MF) and low frequency range (LF). The LF time constant is attrib uted to the presence of a thin oxide film covering the AA2024 T3. More interestingly, the two other time constants are considered to be representative of the coating and suggestive of a double layered morphology. Impedance modulus decreases with increasing immersion time, particularly at the beginning of immersion, which indicates a water uptake and a decrease in the barrier properties. A decrease of the impedance modulus in the LF range is also observed which may be attributed to the increase of the surface area at the metal/coating interface in contact with the electrolyte. However, it can be seen that the diagrams are poorly modified between $168 \mathrm{~h}$ and $336 \mathrm{~h}$ of immersion, showing that the system evolves slowly. High impedance modulus values $\left(\begin{array}{lll}10^{7} & 10^{8} \Omega \mathrm{cm}^{2}\end{array}\right)$ are measured, indicating that high level of corrosion protection can be achieved. The MF time constant at $110 \mathrm{~Hz}$ can be represen tative of a first inner layer at the oxide/coating interface, Whilst the HF time constant at $1001000 \mathrm{~Hz}$ is rather ascribed to a second outer layer in contact with the electrolyte. The two layered
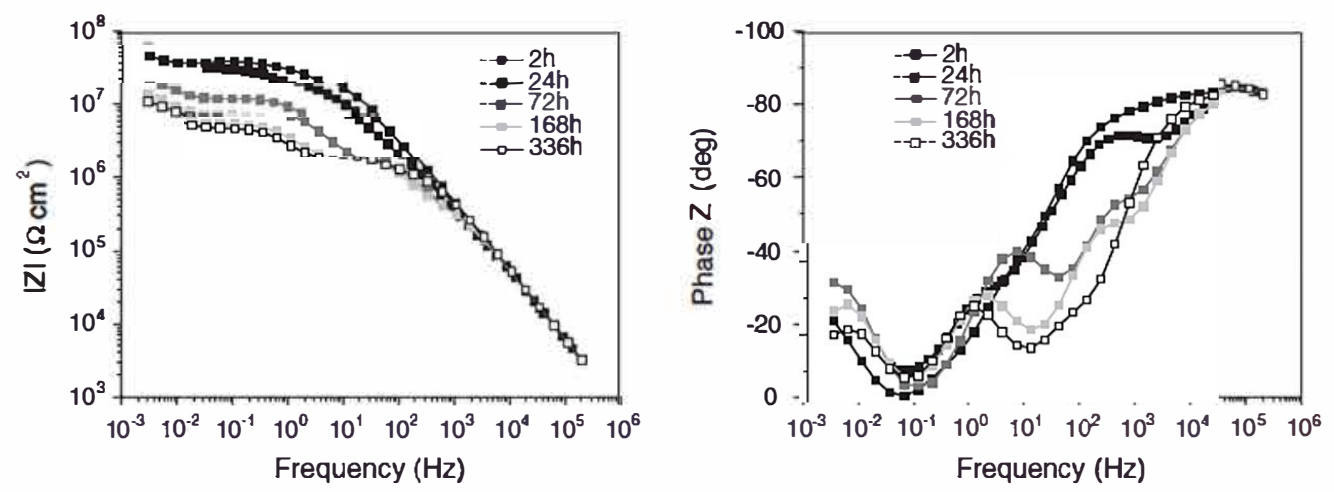

Fig. 8. Electrochemical impedance diagrams (Bode representation) obtained with the $\mathrm{E}_{50} \mathrm{C}_{8} \mathrm{TMS} \mathrm{S}_{\mathrm{so}}$ film for different immersion times in $0.5 \mathrm{M} \mathrm{NaCl}$ solution. 
structure remains difficult to prove, but could be supported by the higher concentration in iodine found in the vicinity of the substrate (Fig. 2). This suggests a locally higher photoacid concentration at the metal/film interface, driving further condensation than in the bulk and the formation of a highly cross linked inner layer.

\section{Conclusions}

A UV driven methodology having many process advantages has allowed the synthesis of a direct to metal protective hybrid coating providing efficient barrier properties on aluminium alloy substrate. The use of photoacid species catalyzing simultaneously diepoxy ROP and organosilane condensation enables fast polymerization rates and highly cross linked siloxane network without the need of solvent or even water. This opens the door to a novel "superpri mer" capable of replacing both surface treatment and primer. A combination of SST and EIS analysis has revealed the best performances of the $\operatorname{poly}(n$ octylsilsesquioxane)/polyether coating. Comparison with a pure polyether film shows that $n$ alkyltrimeth oxysilane is responsible for the enhanced corrosion protection. Its first mode of action is to increase film hydrophobicity. Hydrocarbon chains are able to provide low surface energy, and effectively "shield" hydrophilic groups such as alcohols (polyether network) or silanols (polysiloxane network). A long enough alkyl chain $(n \geqslant 8)$ and sufficient organosilane loadings (50 wt.\%) are necessary to increase the barrier properties. Yet, enrichment in alkyl groups on the air side interface is noticeable at low concentration, this means that further alkyl chains embedded inside the film are also essential to deliver an efficient corrosion resistance. A second effect of $n$ alkyltrimethoxysilane is to generate a silsesquioxane network that complements the barrier effect already provided by the poly ether network. The high degree of condensation attainable under photoacid catalysis is also instrumental in ensuring a minimal number of residual hydrophilic silanols. In addition to these two structural features, further experiments have shown the impor tance of having a relative compatibility between the two noncova lently bound networks. To favour the formation of a homogenous interpenetrated system, too long alkyl chains $(n \geqslant 12)$ raising phase segregation and leading to inefficient protection must be avoided. Thus, the best performances are achieved with the use of the intermediate $\mathrm{C}_{8} \mathrm{H}_{17} \mathrm{Si}\left(\mathrm{OCH}_{3}\right)_{3}$ precursor. Another way to mitigate the incompatibility between the two networks is to pro mote a rapid single step formation. In situ kinetic measurements by RT FTIR has supported the occurrence of kinetically driven path way in which the two poorly miscible polyether and silsesquioxane structures could be "fixed" at the nanometre scale through fast and concomitant cross linking reactions.

\section{Acknowledgements}

This work was carried out in the framework of the MHYRCEA project, with the financial support of Agence Nationale de la Recherche (ANR) under contact ANR 08 MAPR 0003. The authors gratefully acknowledge the partners of the project: Airbus France (Dr. Mélanie Bedu), Airbus Group Innovations (Dr. Sophie Senani), Institute Charles Sadron in Strasbourg (Prof. Christian Gauthier, Dr. Vincent Le Houérou) and ABB (Christophe Jouve).

\section{Appendix A. Supplementary material}

Supplementary data associated with this article can be found, in the online version, at http://dx.doi.org/10.1016/j.corsci.2014.09.006.

\section{References}

[1] E.A. Starke Jr, J.T. Staley, Prog. Aerospace Sci. 32 (1996) 131-172.

[2] M.W. Kendig, R.G. Buchheit, Corrosion 59 (2003) 379-400.

[3] E. Ghali, R.W. Revie, Corrosion Resistance of Aluminum and Magnesium Alloys: Understanding, Performance, and Testing, John Wiley and Sons Inc, Hoboken, USA, 2010.

[4] E. Ghali, V.S. Sastri, M. Elboujdaini, Corrosion Prevention and Protection: Practical Solutions, John Wiley and Sons Ltd, Chichester, England, 2007.

[5] R.L. Twite, G.P. Bierwagen, Prog. Org. Coat. 33 (1998) 91-100.

[6] D.V. Andreeva, E.V. Skorb, D.G. Shchukin, ACS Appl. Mater. Interf. 2 (2010) 1954-1962.

[7] D. Borisova, H. Moehwald, D.G. Shchukin, ACS Appl. Mater. Interf. 5 (2013) 8087.

[8] J.H. Osborne, K.Y. Blohowiak, S.R. Taylor, C. Hunter, G. Bierwagon, B. Carlson, D. Bernard, M.S. Donley, Prog. Org. Coat. 41 (2001) 217-225.

[9] V.S. Saji, J. Thomas, Curr. Sci. 92 (2007) 51-55.

[10] T.L. Metroke, R.L. Parkhill, E.T. Knobbe, Prog. Org. Coat. 41 (2001) 233-238.

[11] D. Wang, G.R. Bierwagen, Prog. Org. Coat. 64 (2009) 327-338.

[12] M.L. Zheludkevich, I.M. Salvado, M.G.S. Ferreira, J. Mater. Chem. 15 (2005) 5099-5111.

[13] T. Sugama, N. Carciello, M. Miura, Thin Solid Films 216 (1992) 249-258.

[14] T. Sugama, J.R. Fair, A.P. Reed, J. Coat. Technol. 65 (1993) 27-36.

[15] K.Y. Blohowiak, J.H. Osborne, K.A. Krienke, U.S. Patent 5849110, 1998.

[16] K.Y. Blohowiak, J.H. Osborne, K.A. Krienke, U. S. Patent 5869140, 1999.

[17] J.E. Hatch, Aluminum: Properties and Physical Metallurgy, ASM International, Metals Park, Ohio, 1984

[18] W.J. van Ooij, D. Zhu, M. Stacy, A. Seth, T. Mugada, J. Gandhi, P. Puomi, Tsinghua Sci. Technol. 10 (2005) 639-664.

[19] D. Zhu, W.J. van Ooij, Corros. Sci. 45 (2003) 2177-2197.

[20] P. Wang, D.W. Schaefer, Langmuir 24 (2008) 13496-13501.

[21] S. Zheng, J. Li, J. Sol-Gel Sci. Technol. 54 (2010) 174-187.

[22] D. Balgude, A. Sabnis, J. Sol-Gel Sci. Technol. 64 (2012) 124-134.

[23] M. Sheffer, A. Groysman, D. Mandler, Corros. Sci. 45 (2003) 2893-2904.

[24] T.L. Metroke, J.S. Gandhi, A. Apblett, Prog. Org. Coat. 50 (2004) 231-246.

[25] T.L. Metroke, O. Kachurina, E.T. Knobbe, Prog. Org. Coat. 44 (2002) 185-199.

[26] P. Wang, D.W. Schaefer, Langmuir 26 (2010) 234-240.

[27] M. Schem, T. Schmidt, J. Gerwann, M. Wittmar, M. Veith, G.E. Thompson, I.S Molchan, T. Hashimoto, P. Skeldon, A.R. Phani, S. Santucci, M.L. Zheludkevich, Corros. Sci. 51 (2009) 2304-2315.

[28] Y.J. Du, M. Damron, G. Tang, H.X. Zheng, C.J. Chu, J.H. Osborne, Prog. Org. Coat. 41 (2001) 226-232.

[29] W.J. van Ooij, W. Yuan, U.S. Patent 5759629, 1998.

[30] J.B. Bajat, I. Milosev, Z. Jovanovic, R.M. Jancic-Heinemann, M. Dimitrijevic, V.B. Miskovic-Stankovic, Corros. Sci. 52 (2010) 1060-1069.

[31] D. Zhu, W.J. van Ooij, Corros. Sci. 45 (2003) 2163-2175.

[32] A. Cabral, R.G. Duarte, M.F. Montemor, M.L. Zheludkevich, M.G.S. Ferreira, Corros. Sci. 47 (2005) 869-881.

[33] W.J. van Ooij, D. Zhu, V. Palanivel, J. Lamar, M. Stacy, Silicon Chem. 3 (2006) $11-30$.

[34] Y. Wang, E. Watkins, J. Ilavsky, T.L. Metroke, P. Wang, B. Lee, D.W. Schaefer, J. Phys. Chem. B 111 (2007) 7041-7051.

[35] D. Raps, T. Hack, J. Wehr, M.L. Zheludkevich, A.C. Bastos, M.G.S. Ferreira, O. Nuyken, Corros. Sci. 51 (2009) 1012-1021.

[36] S.A.S. Dias, S.V. Lamaka, C.A. Nogueira, T.C. Diamantino, M.G.S. Ferreira, Corros. Sci. 62 (2012) 153-162.

[37] D. Grigoriev, D. Akcakayiran, M. Schenderlein, D. Shchukin, Corrosion 70 (2014) 446-463.

[38] C. Sanchez, P. Belleville, M. Popall, L. Nicole, Chem. Soc. Rev. 40 (2011) 696753.

[39] K.Y. Blohowiak, J.W. Grob, J.H. Osborne, U.S. Patent 2008/0111027, 2008.

[40] C.J. Brinker, G.W. Scherer, Sol-Gel Science, Academic Press, San Diego, 1990.

[41] R. Schwalm, UV Coatings Basics Recent Developments and New Applications, First ed., Springer, Berlin, 2007.

[42] L. Ni, N. Moreau, A. Chemtob, C. Croutxe-Barghorn, J. Sol-Gel Sci. Technol. 64 (2012) 500-509.

[43] A. Chemtob, D.-L. Versace, C. Belon, C. Croutxe-Barghorn, S. Rigolet, Macromolecules 41 (2008) 7390-7398.

[44] C. Belon, A. Chemtob, C. Croutxe-Barghorn, S. Rigolet, M. Schmitt, S. Bistac, V. Le Houérou, C. Gauthier, Polym. Int. 59 (2010) 1175-1186.

[45] D. Snihirova, S.V. Lamaka, M. Taryba, A.N. Salak, S. Kallip, M.L. Zheludkevich, M.G.S. Ferreira, M.F. Motemor, ACS Appl. Mater. Interf. 2 (2010) 3011-3022.

[46] J. Tedim, S.K. Poznyak, A. Kuznetsova, D. Raps, T. Hack, M.L. Zheludkevich, M.G.S. Ferreira, ACS Appl. Mater. Interf. 2 (2010) 1528-1535.

[47] S. Penczek, P. Kubisa, R. Szymanski, Makromol. Chem., Macromol. Symp. 3 1986) 203-220

[48] J.V. Crivello, S. Liu, J. Polym. Sci., Part A: Polym. Chem. 38 (2000) 389-401.

[49] Q. Zhu, S. Feng, C. Zhang, J. Appl. Polym. Sci. 90 (2003) 310-315.

[50] A.N. Parikh, M.A. Schivley, E. Koo, K. Seshadri, D. Aurentz, K. Mueller, D.L. Allara, J. Am. Chem. Soc. 119 (1997) 3135-3143. 